\title{
In vino veritas: vinho e aguardente no cotidiano dos sodomitas luso- brasileiros à época da Inquisição
}

\section{In vino veritas: wine and sugarcane spirit in the everyday life of the Luso-Brazilian sodomites during the Inquisition times}

\author{
LuizMott
}

"Quem rindo o vinho bebe, chorando desbebe..."

(Gregório de Mattos, 1695)

\section{Introdução}

São diversas as referências ao consumo de vinho e aguardente nos processos dos sodomitas luso-brasileiros presos pela Inquisição Portuguesa. ${ }^{1}$ Seja como ingrediente constante nas refeições ou merendas mantidas antes ou depois da consumação de atos homoeróticos, quer na residência de um dos amantes, quer em tabernas, ao ar livre e tascas púbicas, seja ainda apontado como álibi dirimente lembrado com vistas a excluir ou atenuar a culpabilidade dos réus na prática do "abominável e nefando pecado de sodomia". De acordo com as palavras de um sodomita português que servia como soldado em Angola nos meados do século XVII: "com uma peroleira de vinho e uma botija de aguardente fazia dos rapazes o que quisesse, porque o vinho e aguardente fazem perder o juízo". ${ }^{2}$ Convém referir, igualmente, que, quando menos, desde a primeira visitação do Santo Ofício às partes do Brasil, já em 1591, era uma preocupação constante, nos interrogatórios inquisitoriais, perguntar ao confessando se "estava no perfeito uso do seu juízo ou se tinha tomado vinho" por ocasião do cometimento do pecado 
ou crime que o levava agora às barras deste Santo Tribunal, visando avaliar o grau de responsabilidade criminal ou intencionalidade do delito. Assim, com base nos processos e sumários inquisitoriais relativos ao pecado nefando, nosso objetivo neste ensaio é reunir e interpretar as informações relativas aos diferentes aspectos dos padrôes de consumo de vinho e aguardente pelos sodomitas e fanchonos espalhados pelo mundo lusitano: ocasiões e situações em que se dava o consumo de bebidas alcoólicas; quantidade, medidas e utensílios ligados ao produto consumido; a utilização destas bebidas, seja como ingrediente visando a socialização, sedução ou dirimente da culpa criminal.

Em mais de 450 processos e 4 mil denúncias de sodomitas e fanchonos inculpados no abominável crime de sodomia registrados nos cadernos e repertórios do Nefando das Inquisições de Lisboa, Coimbra e Évora, encontramos até agora, através da pesquisa computadorizada, 34 referências ao consumo de vinho e aguardente, sendo oito no século XVI, dezesseis no século XVII e dez no século XVIII, a mais recuada datando de 1557 e a mais recente de $1795 .{ }^{3}$ Destas, 25 tratam do consumo de vinho, 7 de aguardente e duas referidas genericamente de "bebida". Treze destes episódios ocorreram no Brasil, dezoito em Portugal, notadamente em Lisboa, e um caso, respectivamente, com portugueses moradores em Angola, Goa e Argel. Dos implicados, 25 são brancos, encontrando-se também um representante de cada uma destas etnias: mourisco, turco, cabra indiano, negro, mulato e mestiço, desconhecendo-se a raça de dois indivíduos.

Todas as sete menções ao consumo de aguardente ocorreram no Brasil, incluindo também três consumidores de vinho e um referido apenas como bebida. Quanto à profissão dos homossexuais envolvidos de alguma forma com o consumo de vinho ou aguardente, temos quatro padres, dois fazendeiros, dois soldados, dois escravos, dois estudantes, dois criados, e um consumidor para as demais categorias: lavrador, moço de Sua Majestade, ferrador, carvoeiro, sapateiro, cirurgião, músico, embarcado, mestre de meninos, serigueiro, esmoler, além de seis sem profissão conhecida.

Quanto à idade das pessoas envolvidas com consumo etílico, o mais jovem tinha 10 anos e o mais velho 68; destes, onze tinham menos de 30 anos, cinco de 30 a 40, e seis com mais de 50 anos. Quanto ao local de residência, predomina Lisboa, com 12 moradores, incluindo ainda no Rei- 
no as vilas de Covilhã, Rabaçal, Porto Alegre, Braga, Évora, Monte Mor. No Brasil, os consumidores de aguardente residiam sobretudo nas Minas Gerais - Mariana, Nazaré e Ouro Preto - mas também moradores no Pará, Rio de Janeiro, em São Luiz do Maranhão, Olinda, São Gonçalo na Bahia; na Capitania de São Paulo, nas vilas de Araritaguaba e Santo Amaro do Guarujá. A partir desta seleta amostra podemos concluir que os sodomitas consumidores de vinho e aguardente refletiam a mesma heterogeneidade étnica, etária, profissional e residencial peculiar a este subgrupo, cuja preferência sexual, no mais das vezes, mantinha-se escondida e clandestina, dado que a sodomia era considerada crime tão grave como o regicídio e a traição nacional. ${ }^{4}$

Não temos condição de avaliar se os homossexuais de antanho consumiam mais ou menos bebidas alcoólicas que o restante da população. Pesquisas modernas associando o alcoolismo como um dos fatores explicativos da homossexualidade há décadas foram descartadas. ${ }^{5}$ A presença exclusiva do sexo masculino nesta amostra deve-se não apenas ao fato de se tratar de uma população predominantemente de amantes masculinos do mesmo sexo, mas também ao padrão cultural dominante em muitas sociedades machistas ou patriarcais, onde o consumo de bebidas alcoólicas está muito associado à confraternização de homens em espaços públicos monossexuais - tabernas e estalagens em particular, onde raramente as mulheres se faziam presentes. Não encontramos na documentação inquisitorial nenhuma referência ao consumo de bebidas alcoólicas nos 29 processos de lesbianismo relativos ao Brasil - o que sugere que o alto consumo etílico entre lésbicas contemporâneas provavelmente é fenômeno historicamente recente. ${ }^{6}$

Ao pesquisar sobre o consumo de álcool entre sodomitas denunciados às inquisiçóes portuguesas, apesar da limitada amostra e de se tratar de tema periférico à caracterização penal do pecado nefando, não obstante, encontramos nos processos pesquisados alusão a uma dezena de termos e situaçôes relativos à cultura material e ao universo da vinicultura, permitindonos assim esboçar um escorço etnográfico sobre esse traço cultural. Nos processos inquisitoriais foram mencionados: vinha, uva, adega, pipa, garrafa, borracha, copo, botija, peroleira, quartinho, taberna, além de algumas medidas de volume que serão citadas ao longo destas páginas. A referência a tais elementos do universo vinário confirma a importância antiga desta be- 
bida na cultura lusitana, quer na metrópole, quer no ultramar, cujos reflexos observam-se no dia-a-dia desta subpopulação de homens amantes do mesmo sexo. Muito poucas são as informações nestes documentos sobre a cultura material da aguardente em terras brasílicas, muito embora fosse a bebida mais consumida pelos colonos: nenhuma referência a cana, canavial, alambique, canada. ${ }^{7}$ Em apenas um destes documentos encontramos a aguardente de cana referida como pinga: datado de 1773, trata-se de uma denúncia contra dois irmãos, a mulata Florência e o crioulo Simão, exescravos, moradores na Freguesia dos Prados, bispado de Mariana. Diz este manuscrito que "Florência mandou a um seu inimigo uma garrafa de aguardente com tantos feitiços dentro, que, colocando-se numa colher de prata a pinga, ficou preta como carvão e o doente logo morreu." ${ }^{8}$ Localizamos apenas três informações sobre recipientes ligados ao armazenamento e consumo da aguardente: "garrafinha”, botija e copo.

\section{Bebendo juntos}

Iniciamos esta reconstituição histórica observando o vinho como ingrediente presente nas refeiçôes ou merendas dos sodomitas mantidas antes ou depois da consumação de atos homoeróticos, quer na residência de um dos amantes, quer em tabernas e outros locais públicos.

João Freire, um jovem criado, morador em Olinda, em 1595, confessou na Mesa do Santo Ofício, quando da primeira Visitação em Pernambuco, que, indo algumas vezes à casa do sapateiro André Lessa, "por importunação e instigação do dito que o provocava, lhe mostrou seu membro viril contra sua vontade, deixando o sapateiro tomá-lo na mão, e certa vez convidou-o para jantar e comeram pão, pacovas e beberam vinho e ele réu bebeu dois copos, mas ele, posto que ficou no seu juízo, não ficou tanto como agora está”. Em seguida, o sapateiro o pôs de bruços e se lançou em cima dele cometendo o abominável pecado de sodomia. ${ }^{9}$

Algumas vezes, faltando vinho em casa, providenciava-se sua compra com vistas a tornar os encontros homoeróticos certamente mais soltos e sensuais: João Antônio, 18 anos, turco, criado de D. Bartolomeu Veiga, morador em Lisboa, em 1557 é acusado de na casa de seu senhor receber furtivamente "moços desbarbados e bem dispostos, criados de fidalgos e também mulheres 
solteiras", ocasião em que mandava buscarpão e vinho, e se abraçavam e beijavam e dormiam juntos. Reconheceu perante os Inquisidores ter mantido mais de uma dezena de encontros sodomíticos dizendo que "sempre estava alegre de vinho quando pecava neste pecado". Foi condenado a prisão perpétua com penas servis nas obras del Rey, recomendado que se apartasse de más conversações, sendo obrigado a comungar três vezes ao ano. ${ }^{10}$

Outro fanchono, Pedro Leonardo, 30 anos, casado, lavrador, natural de Castelo de Tran, na Sicília, preso pela Inquisição de Coimbra em 1616, disse que encontrou-se casualmente com Manuel, 11 anos, filho de um vendeiro de Rabaçal, que fazia-se acompanhar de seu amigo Miguel, ambos a caminho de Lisboa. E que, "estantes à beira de uma estalagem e estando a cear, deu-lhes uva, pão, ovos e meio quartilho de vinho ${ }^{11}$ e dizendo que também ia a Lisboa, aí convidou-os a se agasalharem no campo, distante do povoado, numa estrebaria" e nesta paisagem bucólica, o italiano sodomisou o mais jovem. ${ }^{12}$

Este outro episódio teve lugar em Lisboa, em residência de Manuel de Figueiredo, 24 anos, moço de câmara de Sua Majestade, sita à Cruz da Cata, em 1619, local que servia de ponto de encontro e engate para inúmeros sodomitas alfacinhas. Segundo denúncias do filho do meirinho da Inquisição, "certa vez, enquanto merendavam bolinhos e vinho, saiu Manuel Figueiredo e um tal Pacheco e se fecharam por três horas num aposento onde cometeram somitigarias. "Disse mais, que o anfitrião blasfemava contra Nossa Senhora chamando-a de 'Celestina', e que 'Santa Helena era feia como uma burra', e que 'São Boaventura era amigo de cus'."13

Estalagens, tabernas e casas de pasto eram igualmente procurados pelos sodomitas como locais de encontro e socialização, muitos destes rendezvous entremeados por freqüentes tragos de vinho. O Padre João Pisanis, 50 anos, clérigo de missa, natural de Toulouse, então morador na Calçada de Santo André, em Lisboa, preso em 1560, vestia manto, trançado na cinta e borracha ("vaso de couro com bojo e gargalo estreito, para conter água, vinho ou outro líquido"). Ao ser preso, se pôs de joelhos pedindo perdão com lágrimas e soluços. Quando indagado por sua vida e costumes, "disse que quando tinha 7-8 anos, guardando uma vinha e com outro moço brincavam de ficar um em cima do outro e depois disto lhe ficou uma má inclinação a este pecado". Confessou diversas sodomias com rapazes e foras- 
teiros. Disse mais que na "porta de Santo Antão, [no centro da velha Lisboa], encontrou numa estalagem um mulato vagabundo de 14-15 anos, forro, do Algarve, e convidou-o a pão e vinho e tomou sua natura e meteu-a no seu vaso traseiro". Recebeu pena relativamente branda: "pelo muito atrevimento e pouco temor de Deus, cometendo o mau pecado por muito tempo, sempre agente, que esteja em cárcere estreito e apertado por tempo que mandarem os Inquisidores, obrigado ao jejum a pão e água às quartas e sextas-feiras, uma disciplina às sextas, e após esse tempo, tenha degredo perpétuo para fora do reino". ${ }^{14}$

Foi igualmente numa casa de pasto onde o menino José Gonçalves, 10 anos, encontrou em 1682 um soldado que o convidou a comer pastéis e beber vinho, e na presença de um preto, desatacou suas calcas e o sodomisou sobre um banco. ${ }^{15}$

Em 1644, Antônio Nunes, 28 anos, ferrador, casado, morador em Lisboa, disse que, há sete anos passados, Gaspar de Basto, que tem fazendas e casa de estalagem, velho com mais de 70 anos, levou-o à sua adega e deulhe de beber perguntando-lhe "se acompanhara já com frades e outros desta qualidade", aí meteu a mão na braguilha, encostou-se numa pipa e mandou o moço sodomisá-lo, repetindo a cópula oito dias depois. ${ }^{16}$

Um dos episódios mais simpáticos relacionando o amor homossexual com a bebida remete-nos a São João del Rey, ao lugar conhecido de Lamas da Lagoa, no ano do Senhor de 1752. Trata-se de uma denúncia contra um jovem professor, João Pereira de Carvalho, "mestre de meninos", acusado de praticar "o pecado em que se não pode falar" com seu pupilo, Luís Moreira de Carvalho, 10 anos. Consta que tal professor, então com apenas 12 anos, mandara um recado a seu amado por outro menino dizendo: "Luís, vós, se me quereis bem, eu também te quero, e se me quereis mal, eu também vos quero" e que o fosse encontrar no bananal no lugar que ele bem sabia. Consta que o pai do pupilo, ao tomar conhecimento desta descaração, dissera ao Mestre que "tinha sido chamado em sua casa para ensinar os seus filhos e o fez pelo contrário, ensinando-os somiticarias". Uma testemunha disse ter visto um escrito do mestre nestes termos: "Luís, meu amorzinho, minha vidinha: vinde para o bananal que eu lá vou com a garrafinha de aguardente". Outro denunciante dá versão levemente diversa para o mesmo bilhete: "minha vida, vinde para o bananal que lá tens o que comer e beber". ${ }^{17}$ 
Como vimos, a partir destes exemplos, o vinho e aguardente fizeramse presentes tanto em refeições domésticas, quanto em locais públicos, seja em merendas, em repastos mais substanciosas, acompanhando alimentos variados, entre os quais: pão, pastéis, bolinhos, ovos, pacovas (banana-daterra), uva. Pão e vinho foram a combinação mais comum nestes encontros amorosos, reflexo, certamente, da falta de recursos materiais dos sodomitas e fanchonos luso-brasileiros.

\section{Vinho sedutor}

Em alguns processos e sumários, tendo os amantes do mesmo sexo como réus, transparece clara ou sub-repticiamente a utilização de bebidas alcoólicas como ingrediente facilitador da sedução, conquista ou manutenção de parceiros sexuais.

Tal situação evidencia-se de forma luminar no processo contra o barbeiro André Dias, 39 anos, viúvo, natural de Évora, soldado em Angola em 1652, sendo o sodomita que mais claramente formulou tal assertiva. Pesava sobre si a acusação de ter dormido com outro soldado numa caravela da Armada quando navegava para a África. Apesar de o ato sodômico ter ocorrido debaixo de um cobertor, na calada da noite, tornou-se público, provocando grande escândalo na embarcação. Diga-se en passant que há registros de outros sodomitas que por pouco não foram arremessados ao mar, quando descobertos pelos demais embarcados, temerosos que Deus provocasse o naufrágio do barco como castigo por pecado tão abominável. Cogitaram os marinheiros nesta ocasião denunciar o libertino ao Santo Ofício, mas um soldado dissuadiu os demais, dizendo que o faltoso "estava cheio de vinho, querendo beijar e convidando a muitos soldados para dormir juntos, elhes dava vinho e dádivas para os seduzir". Como só ia acontecer em longas travessias marítimas, cada qual levava em sua matalotagem algumas pipas de vinho, néctar preciosíssimo para alegrar o coração e passar mais rápido o tempo nestas intermináveis viagens transoceânicas. Daí o dito soldado utilizar o vinho como moeda em troca de serviços sexuais de outros embarcados. Um marinheiro ouviu este soldado sodomita dizer que com uma peroleira de vinho e uma botija de aguardente fazia dos rapazes o que quisesse, porque o vinho e aguardente faz perder o juizo. Por seus excessos sodomíticos e etílicos, foi condenado a cinco anos de galés. ${ }^{18}$ 
Também nos Brasis, outro soldado incorre no mesmo deslize sensual motivado pelo excesso da bebida: em 1729, o paulista Inácio Pereira, apelidado o Quereca, servindo no Forte da lha de Santo Amaro, no Guarujá, capitania de São Paulo, é acusado de "cometer os moleques para com ele sumitigar" e que o Vigário "deu-lhe uma correção pastoral, pelo referido, ao que o acusado negou, dizendo que se o fez, estava bêbado, pois é dado à bebida".

Neste outro caso, a bebida aparece como elemento mantenedor da relação homoerótica: em 1621, Thomas Mendes, filho do meirinho da Inquisição de Lisboa, denuncia que Manoel Coelho e Garcia Castelhano copulavam entre si e "o Coelho era o agente e que o Garcia Castelhano lhe pagava os copos e lhe dava dinheiro." ${ }^{19}$ Eis mais uma expressão idiomática daquela época ligada à etno-linguística vinária: "Pagar os copos" como sinônimo do que hoje chamamos de pagar a bebida ou oferecer um trago.

O carvoeiro eborense, Francisco Magalhães, 35 anos, confessou espontaneamente que, em 1646, um mancebo de meã estatura, 25 anos, pouca barba, oficial de agulheiro, morador junto à igreja de São Vicente, pediu-lhe que entrasse na loja de sua casa e lhe deu alguns beijos e abraços "e lhe chamou de mano e pediu que consentisse dormir com ele pelo traseiro e ele denunciante puxou por uma faca para se defender do mancebo". Então o rapaz "o jogou na escada e tentava agarrá-lo de ilharga, aí gritou e acudiram três frades da Igreja vizinha de São Pedro, chamando o mancebo de somítigo. Disse que já tinha ido comprar agulhas no ano passado, ocasião em que "deu-lhe vinho, mais agulhas de presente e um beijo - não se importou porque achou que era efeito do vinho." ${ }^{20}$ Neste caso, a oferta do vinho certamente teve como objetivo quebrar o gelo e liberar a libido, facilitando assim a sedução do desconhecido.

$\mathrm{O}$ vinho entra agora como moeda de barganha na tentativa de comprar o silêncio de um cúmplice devido a uma sedução mal sucedida, evitando que chegasse ao conhecimento das autoridades inquisitoriais, vindo a ameaçar gravemente a vida do sedutor: o padre Diogo Martins Brandão, deão da Sé da Ilha de São Tomé, é denunciado em 1686 junto ao Bispo local, por Manoel Pinheiro, 15 anos, que, estando a medir sal no navio, a caminho do Rio de Janeiro, veio a ele o dito sacerdote convidando-o para ir à sua casa buscar uma carta para seu irmão. Lá chegando, o deão puxou-o para a sua câmara querendo desatacá-lo. Por ter recusado, Padre Diogo pediu segredo, "prometendo-lhe dar meia pipa de vinho". ${ }^{21}$ 


\section{0 poder da aguardente}

Em alguns processos, mais no Ultramar do que no Reino, as bebidas alcoólicas funcionavam como estratégia utilizada pelos mais abastados para seduzir sexualmente ou dobrar as resistências de subalternos a seus avanços homoeróticos. Tal se patenteia neste curioso episódio ocorrido na Capitania de São Paulo em 1741, na Vila de Nossa Senhora da Penha de Araritaguaba. Seu protagonista é o "cirurgião aprovado" Lucas da Costa Pereira, natural da Ilha do Funchal. Contra este reinol constava que "come carne nos dias proibidos, não ouve missa e é acostumado a ter atos sodomíticos sendo agente com vários negros boçais, para cujo fim os sustenta com largueza”. Segundo denúncia do escravo Domingos, natural do Congo, 40 anos, que serviu ao cirurgião por quatro meses, viu seu senhor "ser agente quatro vezes de pé com o capote aberto, em atos sodomíticos com negros minas não batizados e, para os atrair, regalava-os com comida e aguardente brindando-os ele primeiro" e que uma vez pegou também em seu membro. Beneficiou-se este sodomita da largueza territorial da Colônia, pois tendose retirado para as minas de Goiás, jamais foi encontrado pelos agentes do Santo Tribunal. ${ }^{22}$

Também no extremo norte, na Capitania do Pará, outro senhor branco utilizava a aguardente como elemento facilitador de suas conquistas homoeróticas junto à escravaria. Em 1767, João, angolano, escravo dos religiosos do Carmo, 30 anos, disse que ouviu vários negros reclamarem que o senhor Francisco Serrão de Castro acometia seus escravos para pecarem no nefando e que, quando era rapaz, uma vez o dito senhor "o obrigou a segurar em seu membro mijando-lhe nas mãos e dando-lhe depois um lenço para se limpar e um copo de aguardente, recomendando-lhe que não dissesse o que tinha com ele passado". Outro escravo confirma ter recebido o mesmo copo de aguardente em iguais circunstâncias libidinosas. ${ }^{23}$

Novamente a bebida aparece intermediando relações homoeróticas, só que agora tendo como atores sodomitas negros, revelando assim que a utilização deste néctar precioso como elemento de sedução não era apanágio dos senhores brancos, ultrapassando assim as barreiras estamentais.

Em 1693, na Capitania da Bahia, na freguesia de São Gonçalo dos Campos, vários escravos denunciam perante o comissário do Santo Ofício 
que o mestiço Francisco Rodrigues, cativo de Antônio de Moura Rolim, morador em Cajaíba, assediou sexualmente diversos escravos e forros da região. Entre eles, Lázaro, o qual, vindo ao engenho onde vivia Francisco Rodrigues, este lhe deu bebida e disse que "queria lhe dar uma palavra em segredo". E na casa das caldeiras o fanchono o solicitou para o nefando oferecendo-lhe cinco tostões: "estendeu um casacão sobre uma caixa de açúcar e lhe disse que se deitasse para fazer o ofício de mulher que ele faria o de homem, a cuja resolução respondeu ele testemunha dando-lhe com um bordão algumas pancadas e correndo atrás dele para lhe dar mais". Também Manuel Capueiro, escravo guiné, 36 anos - disse que o dito sodomita, "após the oferecer de beber", o convidou a dar uma palavra com segredo, oferecendo-lhe dinheiro e o começou a afagar, lançando-lhe os braços como que o quisesse abraçar". ${ }^{24}$

Outro negro, este morador em Évora, tem seu nome registrado nos Cadernos do Nefando acusado do mesmo crime. Em 1657, um jovem sapateiro de 19 anos, Álvaro Salgado, denuncia que na ermida de Nossa Senhora da Luz, fora da vila, foi ter com ele um negro, Bento Folgado, 50 anos, que se ofereceu para arranjar-lhe um mestre sapateiro onde trabalhasse, propondo que passasse a noite em sua lógea. Cearam e foram para mesma cama, o negro sem camisa e o rapaz vestido. Aí, com a luz apagada, o negro começou a passar a mão pelo corpo do moço até chegar em seu membro viril. Desgostoso, o rapaz interrompeu as carícias, e o negro se aquietou. No meio da noite, contudo, o dito rapaz acordou com o negro em cima de si, e ao gritar, o negro tapou-lhe a boca com a mão e derramou semente de homem no meio de suas pernas. "Na noite seguinte, na mesma ermida, o negro apareceu de novo, oferecendo-lhe vinho; como recusasse, o negro tirou a espada e deu-lhe uma cutilada cortando-lhe o chapéu." Negro ousado e violento, convenhamos!

\section{Bêbados}

Em inúmeros processos, tanto de sodomia quanto de blasfêmia, solicitação ad turpia e outros crimes do conhecimento do Santo Ofício, os inquisidores e seus deputados tinham por hábito indagar sobre o estado de consciência dos réus, num claro reconhecimento de que deviam ser releva- 
das ou consideradas menos graves aquelas faltas cometidas sob forte efeito de bebida. Em Olinda, em 1594, o Visitador perguntou ao pajem João Batista, 15 anos, um dos cúmplices do citado sapateiro André Lessa, se estava o dito sapateiro bêbado ou fora de seu juízo, respondeu que não estava bêbado e que em seu siso estava. ${ }^{25} \mathrm{~A}$ mesma pergunta foi feita a Fernão Roiz de Souza, 25 anos, amante do $1^{\circ}$ Governador e Capitão Geral do Estado do Brasil (1602-1607), Diogo Botelho, inculpado de muitos atos sodomíticos, seja com este seu "caso", seja com marinheiros e forasteiros que perambulavam pelo porto de Salvador, não raras vezes, praticando ménage a trois. Após detalhada acusação dos hábitos homoeróticos deste ilustre Governador da Bahia, consta em seu processo que o Visitador D. Marcos Teixeira teria "perguntado se sabia que os Compliçes estavão em seu perfeito juizo, ou costumavão a sair delle, e a tomarse do vinho... Respondeo que nunca vira os ditos Compliçes fora de seu juizo nem tomados do vinho..." 26

$\mathrm{Na}$ documentação inquisitorial, o estado de embriaguez alcoólica é referido sob diferentes termos: estar alegre de vinho, esquentado pelo vinho, chumbado de aguardente, tomado do vinho, turbado com aguardente, bêbedo, cheio de vinho, dado à bebida. ${ }^{27}$

Chamar alguém de "bêbado" era um dos insultos mais graves na sociedade colonial: na primeira visitação de Pernambuco consta que a mulata Lianor Fernandes estava pelejando com o padre Francisco Teixeira, vigário da igreja de São Pedro Mártir, proferindo "rõis pallavras injuriosas chamando ao ditto padre de bêbado, filho de cornudo e de puta". ${ }^{28}$

Antônio Luís, mulato escravo, filho de mãe mourisca, preso pela Inquisição de Évora em 1575, disse que "estava tomado do vinho quando Gaspar Dias tirou sua natura e deu sobre as queixadas dele réu”. Segundo avaliação dos Inquisidores, por se tratar de "pessoa incorrigível, sendo tão estragado no pecado de sodomia, que não se tinha esperança alguma de emenda e conversão, antes, parece que se trata de pessoa mui prejudicial à república, corrompedor da honestidade dos mancebos", foi condenado à morte na fogueira. ${ }^{29}$

Em Ouro Preto, ano de 1735, Lourenço Ferreira Esteves, serigueiro, natural de Vila Real, entregou carta ao Comissário do Santo Ofício local dizendo que, "por temor do castigo e por temer que os seus escravos o declarem, confessa que, turbado com aguardente, cometeu sodomia com os 
seguintes seus escravos: José Muria; Teresa, Angola; Inácio, Mina; Mariana, Angola e três vezes com o moleque Antônio". ${ }^{30}$ Êta cachaça braba, um verdadeiro viagra gay!

Entre os sodomitas consumidores de vinho e aguardente, encontramos tanto os que apenas esporadicamente tomavam um gole, quanto os habituados a grandes porres. O padre Bartolomeu de Góes, 50 anos, conhecido como "o punhetário", apelido recebido por ser useiro em manipular a genitália dos jovens penitentes no confessionário, morador em Alcântara, no arcebispado de Lisboa, preso em 1605, alegou estar tomado de vinho quando proferiu certos impropérios contra a Santa Fé Católica, num "momento de cólera", pedindo perdão por tamanha desfaçatez. ${ }^{31}$

Diversos são os fanchonos que, ao serem inquiridos na Mesa do Santo Ofício, relatam ter previamente bebido vinho ou aguardente quando cometeram as nefandices que agora os levava às barras do Santo Tribunal. Outro sacerdote, o padre Rui Nunes, 30 anos, morador em Fundão, na freguesia de Covilhã, acusado por vários rapazes de tê-los forçado a atos sodomíticos, disse em sua confissão que, de fato, seduzira um rapaz seu vizinho prometendo ensinar-lhe a ler, escrever, vestir, calçar e dar mil reais, e quando se encontraram, "tinham bebido muito vinho que poderia ter feito alguma coisa que não é lembrado”. Apertado pelos juízes, reconheceu ter praticado a "coxeta", penetração intra-femural, escapando assim de pena mais severa, reservada à sodomia perfeita, i.e., penetração do membro viril desonesto no vazo traseiro com derramação de semente de homem. ${ }^{32}$

Alguns destes homossexuais, como o padre Fernão Pereira da Costa, 57 anos, cabra natural de Goa, morador em Porto Alegre, no Alto Alentejo, detido em 1620, mesmo dentro dos cárceres secretos do Tribunal da Fé, nem por isto abandonou sua compulsão pela bebida. Segundo denúncia de frei Fernando Mendonça, estando ambos presos nos cárceres há 20 dias, viu o dito padre e outro cristão novo chamado Flor de Lis "falarem palavras desonestas com outros presos e presas, pois bebe muito vinho e instiga os presos e presas a não se confessarem, dizendo que muito cedo hão de ter uma hora muito formosa em que todos serão soltos e livres com muita honra”. Foi condenado a seis anos de degredo na Ilha do Príncipe. ${ }^{33}$

O maranhense Francisco Coelho, 50 anos, descendente de pais açorianos, casado, dono de fazenda e um sítio de farinha em Majoba, a duas 
léguas de São Luís, é dentre os sodomitas sobre quem mais detalhes sabemos a respeito de seus excessos etílicos. Em 1672 é acusado de "cometer por várias vezes, com brancos e índios, o pecado nefando". De acordo com as acusaçôes de diversos vizinhos, inclusive de sua própria esposa, quando o réu bebia ou estando bêbado, praticava muitos desatinos, querendo manter cópula anal com ela, "chamando os escravos para dormir em sua rede". O excesso de aguardente realmente tirava-o do sério, tanto que, certa vez, hospedado na residência de um seu conhecido, "indo fora fazer suas necessidades, ajudado pelo dono da casa, pegara na sua natura dizendo se lhe servia aquilo nas mãos, levando uns pescoções sob umas pacoveiras". Um de seus cúmplices, o índio Pascoal, disse que "seu senhor certa vez lhe deu tanto aguardente a beber e que depois de bêbado tivera dele o que quis, comunicando por detrás". Oura vez, "indo à busca de um novilho na Ilha de São Francisco, bêbedo, na casa do alferes, na rede, pegara a um negro da terra seu escravo pelo cós da ceroula, chegara-o para si e o metera entre as pernas segurando-o muito bem entre as pernas, indo-lhe desatacando as ceroulas, querendo comunicar por detrás, o que com efeito fizera se ele e outro morador não acudissem logo a entravar e desviar o pecado que determinava cometer." Passados uns tempos, foi encontrado "ao meio-dia, deitado bêbado numa estrada, com o braço por cima de um rapaz índio e, chamando ao réu, este lhe disse que se fosse com todos os diabos". O pai do índio Pantaleão disse que seu filho reclamava muito que seu senhor queria embebedá-lo.

Em sua primeira prisão, o Promotor do Maranhão determinou averiguar "se o acusado estava no seu juízo ou bêbado" quando cometeu tamanhos desatinos. Ao que várias testemunhas disseram que de fato estava fora de seu juizo, e que era mesmo viciado na bebida.

Quatro anos após sua primeira denúncia, as culpas contra Francisco Coelho só faziam crescer, incluindo detalhes pitorescos e inéditos das ousadias cometidas por este incorrigível sodomita e bebum maranhense. Uma das testemunhas disse que ouviu-o dizer para o índio Rodrigo: "ô somítigo, passa pera cá que eu te quero cortar esse caralho porque é maior que o meu! E o dito réu pegou no índio qual debaixo e qual de cima e à noite, depois de beberem uma botija de aguardente do engenho da Andiroba, saíram passando por entre uns pés de algodão, fizeram fogo para beberem fumo e andando bêbados qual debaixo qual de cima, ouviu dizer ao índio: deita-te aqui 
somítigo e viu Francisco Coelho pegar o índio pelas gadelhas e ambos caíram no chão e andaram em cima um do outro. E que vira o dito estar medindo seu membro com o dito índio e juntava um com o outro e lhe ouviu dizer - o teu é maior e ele testemunha o repreendeu, mas ele lhe respondeu que o índio era seu escravo, que podia fazer dele o que quisesse... e que chamava o índio Cunhã Caraíba, que vem a ser, nessa língua, sua mulher”. Apesar de detalhes tão picantes, inclusive informações etnolingüísticas, após longos sumários realizados no Maranhão, concluem os Inquisidores em Lisboa que, de fato, o acusado perdia o juizo quando, sob efeito da aguardente, mas tudo indicava que essas acusaçōes não passavam de ardilosa calúnia de sua mulher, insatisfeita com o marido e desejosa de ver-se livre da companhia de um bêbado contumaz. Foi absolvido da culpa de sodomia! ${ }^{34}$

Também em Minas Gerais, outro sodomita aponta a mistura da aguardente com o "pito" como responsável pela perda do juízo. Infelizmente, é impossível saber de qual fumo se tratava em ambos os casos: se o tabaco ou a maconha. Suspeitamos que no caso acima comentado, no Maranhão seiscentista, tratava-se da Nicotiana tabacum, L., enquanto no episódio a seguir, em Minas Gerais, "pito" equivalia a Canabis sativa, L. ${ }^{35}$ Em 1749, em Vila Rica, na freguesia de Nossa Senhora da Conceição, o músico açoriano Antonio do Carmo denuncia-se perante o Comissário Félix Simões que, "para desencargo de sua consciência e por não poder ir a Lisboa, confessava ter pecado no nefando como agente e paciente com Valentim Pereira, rapaz pardo morador em sua casa, morador com seu pai na Passagem do Ribeirão, e tal fatalidade lhe sucedera há dois anos e meio, e que, há 15 meses passados, estava chumbado de aguardente em Congonhas do Campo, numa festa de S. José dos Pardos, teve um ato de sodomia sendo agente e paciente com um moleque cujo nome ignora e que com outros músicos rapazes por muitas vezes se deitara na cama e com eles estava com brincos desonestos fazendo pulsões nas mãos dos ditos rapazes, outras vezes por entre as pernas, e que os ditos rapazes eram João Antunes, mulatinho; Felipe Nunes, pardo; José Coelho, filho do Capitão; Tomás Espírito Santo, ajudante do Tenente e que todas as vezes estava esquentado com aguardente e com pitar". Concluiu dizendo estar arrependido e prometendo se emendar do dito vício e não tornar a beber aguardente nem usar do pito. ${ }^{36}$ 
Também heterossexuais e bissexuais confessam-se perante o Tribunal da Fé de terem praticado cópula anal sob forte efeito de bebidas alcoólicas: em 1795, um tal Gregório Freire Correia, lisboeta, disse que esquentado pelo vinho, penetrou o vaso traseiro de sua mulher D. Margarida Cândida de Almeida, que consentiu só para o satisfazer. E novamente, "esquentado muito pelo vinho, foi passear e encontrou dois soldados e os convidou para consentirem no mesmo pecado que minha mulher tinha caído e com um soldado de Alencastre não conseguiu e com o de Setúbal, que disse que estava pronto, conseguiu e mais tarde nesta mesma noite, encontrando-se outro soldado do $2^{\circ}$ Regimento da Armada, convidou-o para o mesmo delito ao que ele estava pronto. Sabendo ser culpa tão grave, veio pedir perdão". ${ }^{37}$

Outro beberrão aficionado à sodomia heterossexual remete-nos ao Arraial de Nossa Senhora de Nazaré, nas Minas Gerais, no ano do Senhor de 1751. Maria Álvares Pimentel denuncia que seu marido, o caboclo João Leite do Prado, não só a forçava a suportar a cópula anal, como "cuspia-lhe nas partes vivendas por desprezo", ameaçando-a de morte se viesse se confessar. É feito sumário de culpas e conclui-se que este caboclo mineiro realmente perde o juizo com bebidas, e, segundo confirma sua própria filha, "matrimoniava sua mulher pelo sesso". ${ }^{38}$

\section{Amnésia etílica}

Alguns sodomitas alegaram que tomados do vinho, ou esquentados pela aguardente, tiveram perda temporária da memória, tornando-se irresponsáveis por seus crimes libidinosos: se de fato sofreram de amnésia etílica ou tal esquecimento e falta de controle não passava de desculpa oportunística, jamais poderemos saber.

O jovem mourisco forro Gil, 20 anos, "de meã estatura, desbarbado, anda vestido de vermelho, com calças de pelote”, preso em 1566, acusado de ter agarrado e sodomizado um rapaz cristão, disse que bebera vinho na ocasiāo do pecado, um quartinho e meio, e que estava bêbado e não sabia o que fazia. Acrescentou mais um atenuante à sua defesa: que "em sua terra, sendo mouro, era costumado a dormir com moços por detrás, porque disto [na 
Berbéria] não tinha outra pena senão metê-lo na cadeia e pagar dinheiro e soltá-lo, mas que depois de cristão nunca mais cometera este pecado". Meticulosos, os inquisidores ordenam averiguação e constata-se, que de fato, o mourisco estava bêbado quando cometeu o abominável pecado de sodomia, razão pela qual teve pena relativamente branda: foi sentenciando a remar seis anos nas galés Del rei, sem soldo, com seqüestro de seus parcos bens. ${ }^{39}$

Outros sodomitas alegaram em sua defesa a mesma desmemória causada pelo excesso de bebida: Simão de Brito, 34 anos, natural e morador em Braga, no Minho, preso em 1620 por suspeitas no pecado nefando, apresentou defesa alegando que "se toma muito do vinho e fica doido sem juízo, tanto que num dia de São João, um touro que matava gente estava solto e todos fugiram e ele réu se deixou ficar e o touro o levou nos cornos e por milagre não o matou". ${ }^{40}$

Outro que se disse desmiolado devido à bebedeira foi o mestre cozinheiro Antônio Pereira, pardo, 68 anos, filho de escravos, morador em Lisboa, preso em 1600. Confessou que certa noite, "estando deitado na cozinha, em casa de seu senhor, bêbado e sem saber o que fazia, chegou Bastião e meteu o membro em sua boca, [em seguida ele] tomou o membro na mão, olhou e disse que fosse embora e não entrasse mais na cozinha. Depois Bastião contou a outras pessoas, seus inimigos, que o ensinaram a vir confessar". Em sua defesa, o procurador disse que o réu é bom cristão e cumpre suas obrigações, que foi casado duas vezes e tem muitos filhos, que teve diferenças com muitos criados e sempre dormiu na cozinha que era o lugar mais público da casa; que é muito velho e doente, sem forças para cometer tal ato, concluindo com o argumento pétreo: "o réu bebe vinho que o tira do juizo e muitas vezes lhe faziam muitas travessuras e torpezas". ${ }^{41}$

Termino este repertório de sodomitas que alegaram estar bêbados ou sob efeito da bebida como atenuante para seus atos pecaminosos, com uma carta escrita em 22 de março de 1753, no Rio de Janeiro, por um desconhecido minerador, enviada à Inquisição de Lisboa, onde diz: "Eu, Bernardo Gomes da Costa, me denuncio perante Vossas Mercês da culpa abaixo expressada: estando fora do juizo por demasia de vinho chamei ao escravo mina Francisco, de Goiás, estando nas minas de Paracatu, sendo paciente do negro, há 3 anos passados, não tendo confessado antes por estar preso." ${ }^{42}$ 


\section{0 vinho como ritual e mezinha}

Os processos de sodomia que nos têm servido de matéria-prima neste ensaio fornecem ainda algumas interessantes e pouco conhecidas pistas etnográficas sobre aspectos da cultura do vinho na região mediterrânea. Eis um ritual amatório utilizando o vinho como ingrediente: em 1661 a Santa Inquisição recebe a denúncia de que Manoel Ribeiro, 22 anos, olhos azuis, claro, cabelo castanho, baixo, "andava amigado com um turco de quem era escravo e usava dele como sua mulher" e depois largou-o mandando ganhar pela cidade o seu jornal enquanto não se resgatasse. Consta que depois que este guapo lusitano se amigara com mouras e adotara "o costume dos mouros galantes e namorados, dando um corte em seu braço esquerdo na frente de uma enamorada e derramando no vinho o bebera fazendo demonstração de seu amor e algumas vezes repetira o mesmo, cortando do pulso até o lombo" e viu-o dar seis ou sete feridas. Era muito amigo dos mouros, comendo e bebendo com eles" ${ }^{43}$

Agora o vinho é usado como ingrediente na preparação de mezinha para curar uma chaga anal: em documento sem data, dos meados do século XVIII, informa-se que um moço de embarcaçōes e fragateiro de nome José, residente em Belém, nos arredores de Lisboa, 25 anos, "agarrando um menino de 3 anos incompletos, filho de um chocolateiro francês, o levou para o armazém do qual saiu a criança chorando muito, toda ensangüentada e rasgado o orifício com a pica. Chamado o médico, este aplicou-lhe vinho tinto cozido com menta". ${ }^{4}$

Em outros documentos relativos ao Brasil, sobretudo denúncias contra supostos feiticeiros, também nos meados dos setecentos, novamente encontramos o vinho utilizado como ingrediente curativo: a uma menina possessa pelo demônio, no Rio de Janeiro, "o médico mandou dar-lhe uma colher de vinho com açúcar" e uma "feiticeira" de Sabará, MG, para curar pessoas "acometidas por calundus, usava um remédio que compóe de vinho e do suco de várias ervas que pisa para o dito efeito".

A utilização de vinho e aguardente em rituais de cura e feitiçaria fica como tema para um próximo ensaio. 


\section{Notas}

${ }^{1}$ Comunicação apresentada no Simpósio Drogas e Álcool na História do Brasil, séculos XVI-XIX, Universidade Federal de Ouro Preto, Mariana, 25/27-6-2003.

${ }^{2}$ Arquivo Nacional da Torre do Tombo, Inquisição de Lisboa, Inquisição Lisboa, Processo 1467. [Doravante, abreviado ANTT, IL, Proc.]

${ }^{3}$ Mott, Luiz. "Pagode português: a subcultura gay em Portugal nos tempos inquisitoriais" Ciência e Cultura, vol.40, fevereiro 1980:120-139.

${ }^{4}$ Mott, Luiz. "Justitia et misericórdia: A Inquisição Portuguesa e a repressão ao abominável pecado de sodomia”, in Novinsky, A. \& Tucci, M.L. (Eds) Inquisição: Ensaios sobre Mentalidade, Heresias e Arte. S. Paulo, EDUSP, 1992:703-739.

${ }^{5} \mathrm{O}$ problema do alcoolismo foi largamente reconhecido na sociedade ocidental desde o século XVIII, quando a disponibilidade de bebidas destiladas baratas tornou-as acessíveis a um largo número de pobres e outras pessoas excluídas que passaram a sufocar suas mágoas no licor. $\mathrm{O}$ papel que o álcool pode gozar no relaxamento das inibiçōes sexuais também foi reconhecido desde a antiguidade, associando o deus Dionísio e Baco às celebraçôes orgásticas. Cf. Forest, Gary G. Alcoholism and Human Sexuality. Springfield, IL, Charles Thomas Editor, 1983; Hirschfeld, Magnus. Der Einfluss des Alkohols auf das Geschlechtsleben. Berlin, Michaelis, 1906; Israelstam, S. \& Silvia Lambert. "Homosexuality as a cause of alcoholism: a historical review", International Journal of the Addictions, 18 (1983), p.1085-1107; O'Farrell, T. , Carolyn Weyland, Diane Logan. Alchool and Sexuality: An Annotated Bibliography on Alcoholism, and Sexual Behavior. Phoenix, Oryx Press, 1983.

${ }^{6}$ Belini, Ligia. A Coisa Obscura: Mulher, sodomia e Inquisição no Brasil Colonial. São Paulo, Editora Brasiliense, 1987.

${ }^{7}$ Aguardente, segundo o Dicionário Moraes, é "álcool extraído do vinho, dos cereais, da cana, das frutas doces e quaisquer outros produtos sujeitos a fermentação e destilação." Canada, segundo o mesmo dicionarista, é "antiga medida portuguesa de líquidos que continha quatro quartilhos ou a $12^{\text {a }}$ parte de almude ou 2,662 litros".

${ }^{8}$ ANTT, IL, Caderno do Promotor, n. 130. Segundo o dicionarista Moraes, pinga é sinônimo de vinho bom, licor ou rapé de boa qualidade. "Estar com a pinga" era usado no mesmo sentido de estar embriagado. Nenhuma associação direta a aguardente de cana. Cachaça, por sua vez, já no século XVIII referia-se a aguardente ordinária extraída do mel ou borras de melaço e das limpaduras da cana de açúcar. Já era usado no sentido de "gozo em fazer alguma coisa por paixão ou hábito".

${ }^{9}$ ANTT, IL, Proc. 2557.

${ }^{10}$ ANTT, IL, Proc. 1600.

${ }^{11}$ Quartilho: segundo Moraes, "equivale a quarta parte de uma canada, ou 35 centilitros. No Brasil, correspondia à canada de Portugal". Quartinho: "moeda equivalente a quarta parte da moeda de $4 \$ 800$ ou $1 \$ 200$ réis". Segundo o Dicionário Aurélio, quartilho era "antiga unidade de medida de capacidade para litros, equivalente à quarta parte de uma canada, i. e., 0,6655 litro". 
${ }^{12}$ ANTT, Inquisição de Coimbra, Proc. 3094.

${ }^{13}$ ANTT, IL, Proc. 10093.

${ }^{14}$ ANTT, IL, Proc. 1619.

${ }^{15}$ ANTT, IL, 13 Caderno do Nefando, 143-6-38, fl. 34.

${ }^{16}$ ANTT, IL, 60 Caderno do Nefando, 143-6-33, fl. 136.

${ }^{17}$ ANTT, IL, 20 Caderno do Nefando, 149-7-698, fl. 192.

${ }^{18}$ ANTT, IL, Proc. 1467. Peroleira, segundo Moraes, é "botija de barro grossa e comprida, afunilada para baixo, em que se guardam azeitonas". Botija, por sua vez, é "o vaso de barro de forma cilíndrica, como a da garrafa, gargalo curto e pequena asa ou sem ela, para vinagres, azeites, etc." Segundo o Aurélio, botija é "vaso cilíndrico, de grés, de boca estreita, gargalo curto e uma pequena asa".

${ }^{19}$ ANTT, IL, Proc. 9467.

${ }^{20}$ ANTT, IL, $1^{\circ}$ Caderno do Nefando Évora, 145-5-23, fl. 26.

${ }^{21}$ ANTT, IL, $14^{\circ}$ Caderno do Nefando, 143-6-39, fl. 62. Pipa, segundo Moraes, continha 25 almudes, variando contudo seu volume de região para região. Um almude equivalia a 12 canadas, ou seja, 31,94 litros.

${ }^{22}$ ANTT, IL, $19^{\circ}$ Caderno do Nefando, 143-7-43, fl. 411.

${ }^{23}$ ANTT, IL, Proc. 12894.

${ }^{24}$ ANTT, IL, 15 Caderno do Nefando, 143-6-40, fl. 227.

${ }^{25}$ Denunciaçōes e confissões de Pernambuco, 1593-1595, p.280.

${ }^{26}$ Segunda Visitação do Santo Ofício às partes do Brasil, 1618, p.383.

${ }^{27}$ Eis a definição que o Moraes dá para bêbedo (mais usado do que bêbado): "aquele que tem o juízo perturbado pelo excesso de vinho ou de qualquer outra bebida alcoólica ou por excessivo uso do ópio, do tabaco, etc. Pessoa dada a bebedice, a embriaguês; nome que se dá a um homem desprezível, diz-se: 'é um patife, um canalha, um bêbedo', também a mulher descarada, sem pejo".

${ }^{28}$ Denunciações e confissōes de Pernambuco, 1593-1595, p.355.

${ }^{29}$ ANTT, Inquisição Évora, Proc. 5013.

${ }^{30}$ ANTT, IL, Caderno do Nefando, no 821.

${ }^{31}$ ANTT, IL, Proc. 1312.

${ }^{32}$ ANTT, IL, Proc. 1967.

${ }^{33}$ ANTT, IL, Proc. 6789.

${ }^{34}$ ANTT, IL, Proc. 1717.

${ }^{35}$ Mott, Luiz. "A maconha na história do Brasil", in A . Hennan (Ed), Diamba sarambamba: Textos sobre a maconha no Brasil. São Paulo, Editora Ground, 1986:117-135.

${ }^{36}$ ANTT, IL, 20 Caderno do Nefando, 149-7-698, fl. 89.

${ }^{37}$ ANTT, IL, 20 Caderno do Nefando, 149-7-698, fl. 362 . 
${ }^{38}$ ANTT, IL, 20 Caderno do Nefando, 149-7-698, fl. 254.

${ }^{39}$ ANTT, IL, Proc. 2033.

${ }^{40}$ ANTT, Inquisição de Coimbra, Proc. 5437.

${ }^{41}$ ANTT, IL, Proc. 5882.

${ }^{42}$ ANTT, IL, 20 Caderno do Nefando, 149-7-698, fl. 138.

${ }^{43}$ ANTT, IL, 12 Caderno do Nefando, 143-6-37, fl. 158.

${ }^{44}$ ANTT, IL, 20 Caderno do Nefando, 149-7-698, fl. 121.

\section{Resumo}

Com base nos processos e sumários inquisitoriais da Torre do Tombo, relativos ao nefando pecado de sodomia, interpretamos as informaçôes relativas aos diferentes aspectos dos padróes de consumo de vinho e aguardente pelos sodomitas e fanchonos do mundo luso-brasileiro: ocasiōes e situações em que se dava o consumo de bebidas alcoólicas; quantidade, medidas e utensílios ligados ao produto consumido; a utilização destas bebidas como ingrediente visando a socialização, sedução ou dirimente da culpa criminal dos amantes do mesmo sexo.

Palavras-chave: Sodomia, Escravidão, Vinho.

\section{Abstract}

Sur la base des procès et sommaires de l'Inquisition Portugaise, conservés dans les archives Torre do Tombo de Lisbonne, relatifs à l'abominable péché de sodomie, nous analysons les informations concernant les différents aspects des normes de la consommation du vin et de l'eau-de-vie par les sodomites et "fanchonos" du monde luso-brésilien: les occasions et situations où ils sadonnaient à la consommation de boissons alcooliques; la quantité, les mesures et les ustensiles rattachés au produit consommé; l'utilisation de ces boissons comme ingrédients visant la socialisation, la séduction ou l'empêchement de la culpabilité criminelle des amants du même sexe. Keywords: Sodomy, slavery, wine.

(recebido em maio de 2004 e aprovado em outubro do mesmo ano) 